\title{
Can Emerging Markets Float? Should They Inflation Target? ${ }^{1}$ \\ Barry Eichengreen \\ University of California, Berkeley \\ Revised, February 2002
}

\section{Introduction}

The hot debate over the best monetary-cum-exchange-rate regime for developing countries shows no signs of cooling down. The Asian crisis and its fallout in Latin America and Eastern Europe have convinced many observers that soft currency pegs are crisis prone and that emerging markets should embrace greater exchange rate flexibility. The Turkish crisis reinforced that view. But worries that greater flexibility will impede market access, hinder financial development, and undermine rather than underpin financial stability have led others to advocate moving in the opposite direction -- that is, hardening the peg by installing a currency board or dollarizing. ${ }^{2}$ While there are prominent examples of countries that have moved both ways -Ecuador and El Salvador have dollarized while Brazil has embraced greater flexibility -- many developing countries continue to occupy the middle ground in the sense of making extensive use of their reserves so as to limit the variability of their exchange rates. ${ }^{3}$

\footnotetext{
${ }^{1}$ Revision of a paper presented to a seminar at the Central Bank of Brazil. An earlier version was presented at the Bank of England. For helpful comments I thank Lawrence Ball, Paul Masson, Rick Mishkin, Peter Sinclair, Lars Svensson, Ted Truman, and John Williamson, as well as seminar participants at both institutions.

${ }^{2}$ I use the term "dollarization" generically to denote the adoption of a major (international) currency, be it the dollar, the euro or another unit.

${ }^{3}$ Calvo and Reinhart (2000) are leading exponents of the view that many emerging markets exhibit "fear of floating" -- that, despite being reclassified by the IMF as embracing a greater degree of exchange rate flexibility, they continue to intervene heavily to limit the actual variability of the currency.
} 
The one thing all of these regimes have in common is that none is an entirely comfortable solution to the monetary dilemma. Flexible rates tend to fluctuate erratically, especially if abandonment of a peg leaves a country without a nominal anchor, a clear and coherent monetary policy operating strategy, and credibility in the eyes of the markets. Unilateral dollarization limits policy flexibility, gives the country resorting to it no voice in the monetary policy it runs, and sacrifices seigniorage revenues. And ad hoc intervention to limit the variability of the exchange rate in the absence of a credible commitment to a transparent, coherent, and defensible monetary strategy is unlikely to inspire confidence; attempting to prevent the exchange rate from moving beyond set limits under these circumstances can render the central bank and its reserves sitting ducks for speculators. That none of these options is particularly appealing is, if course, the dilemma of a world in which markets are international but governments are national. It is why authors like Mundell (1997) and Cooper (1999) see a global currency and a global central bank as logical consequences of the globalization of markets.

Notwithstanding this vision for the future, countries opening their economies to capital flows will be forced for the present to choose from this limited menu of hard pegs (currency boards, dollarization), implicit target zones (de jure floating but de facto intervention to limit the variability of the exchange rate), and greater flexibility. ${ }^{4}$ Other authors have made the case for

${ }^{4} \mathrm{~A}$ further option, the adjustable peg, may be viable for countries with capital controls, as the experiences of China and Malaysia have shown. I disregard this option here on the grounds that trends in technology and policy (domestic financial liberalization, in particular) will lead additional countries to liberalize their international financial transactions, limiting those to which this option is relevant. 
the first two options, what can be called hard and soft or loud and quiet pegs. ${ }^{5}$ In this paper I consider the viability of the third.

Calling for emerging markets to abandon the exchange rate as an anchor for policy compels those issuing the call to offer an alternative. ${ }^{6}$ The leading candidate is inflation targeting. ${ }^{7}$ The task I take on in this paper is to assess whether inflation targeting offers a viable alternative to an exchange-rate based monetary policy regime.

There has been some analysis of inflation targeting in emerging markets, most of it recent (the pioneering work is Masson, Savastano and Sharma 1997; see also Eichengreen, Masson, Savastano and Sharma 1999, Christoffersen and Wescott 1999, Mishkin 2000a, Mishkin and

${ }^{5}$ On dollarization, see Hausmann (1999) and Calvo (2000a). On bands and pegs for emerging markets, see Williamson (2000). In order to reduce effective options to three, I lump together under the heading of "intermediate regimes" pegs, bands and crawls a la Williamson and implicit strategies to limit exchange rate flexibility a la Calvo and Reinhart (2000), since both are monetary policy strategies framed in terms of the level of the exchange rate, while neither hardens the peg to the extent of a currency board. This follows the policy literature on target zones, which encompasses both hard and soft zones (that is, with and without buffers and escape clauses) and loud and quiet zones (in other words, those that are announced and unannounced).

${ }^{6}$ Not all of the advocates of greater flexibility take this additional step. Calvo (2000b) criticizes contributions to this literature, with no little justification, for failing to specify the alternative to an exchange-rate based policy regime.

${ }^{7}$ Brazil, Chile, Colombia, Israel, the Czech Republic and Poland all adopted inflation targeting in conjunction with a recognition of the need to widen or abandon an exchange rate band. Clearly, inflation targeting and flexible exchange rates are not synonymous, although, as Calvo (2000b, p.28) writes, there is a tendency to erroneously identify inflation targeting with flexible rates. Flexible rates can be backed by no coherent monetary policy operating strategy of any kind or by a number of alternatives to inflation targeting. The other options for policy are monetary targeting, which is impractical in emerging markets (and most other places) because of the instability of the relationship between monetary aggregates and policy targets, and nominal income targeting, which has formidable data requirements and has never been tried. Another option is the so-called Taylor rule for monetary policy, whose connection to inflation targeting I elaborate below. 
Savastano 2000, Bogdanski, Tombini and Werlang 2000, Devereux and Lane 2000, Jiri 2000, Morande 2000, and Schaechter, Stone and Zelmer 2000). But none of these studies has considered the entire range of issues. And most have failed to distinguish between openeconomy and developing-country aspects of inflation targeting.

I organize my discussion as follows. Section 2 defines inflation targeting and reviews some conceptual issues relating to its implementation. (Readers familiar with this literature may want to skip or skim this material.) Section 3 then asks what is distinctive about inflation targeting in open economies. Issues that arise under this heading include susceptibility to external shocks and the sensitivity of output and inflation to the exchange rate. Section 4 then asks what is distinctive about inflation targeting in emerging markets. Topics under this heading include passthrough, the difficulty of forecasting inflation, liability dollarization, and credibility issues.

The conclusion then returns to question of whether inflation targeting is an option for emerging markets.

\section{General Considerations ${ }^{8}$}

I define inflation targeting as a monetary policy operating strategy with four elements: an institutionalized commitment to price stability as the primary goal of monetary policy; mechanisms rendering the central bank accountable for attaining its monetary policy goals; the public announcement of targets for inflation; and a policy of communicating to the public and the

\footnotetext{
${ }^{8}$ There exist more complete and authoritative surveys of the literature on inflation targeting than I am able to provide here, for example, Bernanke et al. (1999).
} 
markets the rationale for the decisions taken by the central bank. ${ }^{9}$ Institutionalizing the commitment to price stability lends credibility to that objective and gives the central bank the independence needed to pursue it. Mechanisms for accountability make this pursuit politically acceptable and impose costs on central banks that are incompetent or behave opportunistically. Announcing a target for inflation and articulating the basis for the central bank's decisions allows these mechanisms to operate.

The multi-dimensional nature of this definition explains why there is no consensus about which emerging markets are inflation targeters. Brazil, Chile, the Czech Republic, Israel, South Africa, Poland, Colombia, Thailand, Mexico, the Philippines and South Korea are all cited in this connection. ${ }^{10}$ But while all of these countries have announced numerical targets for inflation, not all of them have put in place the other elements of inflation targeting as defined above. At the time of writing, most observers would probably draw the line between the first and last six countries, classifying only the former as full-fledged inflation targeters.

One can further distinguish "strict" inflation targeting from "flexible" inflation targeting. Strict inflation targeting is when only inflation enters the central bank's objective function, flexible inflation targeting when there is also a positive weight on other variables, output for example (Svensson 1999). (Even with strict inflation targeting there is still a positive weight on output in the policy reaction function insofar as the information content of the output gap is

${ }^{9}$ Others would add following an information-inclusive strategy where the variables to which the central bank responds are not limited to, say, current inflation and the output gap, and/or using an inflation forecast as the intermediate guide for monetary policy.

${ }^{10}$ Such lists are constantly changing. Thus, in June 2001 Hungary joined the inflation targeting club "implicitly," while Thailand, according to some, backed away from full-fledged inflation targeting by embracing a more exchange-rate oriented strategy (J.P Morgan 2001, p.11). 
useful for forecasting inflation. ${ }^{11}$ ) Since few central banks and polities are prepared to disregard all other variables under all circumstances, flexible inflation targeting is the policy-relevant case. $^{12}$

This has a number of implications. Most obviously, whereas a central bank that targets inflation strictly will attempt to hit that target as quickly as possible under all circumstances (where the feasible speed depends on the control lag from its policy instruments to inflation), a central bank that pursues flexible inflation targeting will tend to push inflation toward its target more gradually. It will balance the benefits of minimizing the variability of inflation against the costs of creating additional variability in the other variables that enter its objective function.

So defined, inflation targeting is a "target rule," where policy is formulated to hit an appropriately weighted set of ex ante specified policy objectives. The question is how to move from a target rule to an "instrument rule" -- that is, settings for the policy instrument or instruments as a function of the information available to policy makers. ${ }^{13}$ This is not straightforward in a complex economy. ${ }^{14}$ Three imperfect solutions are to fly by the seat of the

${ }^{11}$ I show this below using a simple model. De Brouwer and O'Regan (1997) also show this using a simulation model that inflation targeting which ignores the information content of output deviations results in not just more variable output but more variable inflation as well.

${ }^{12}$ Calvo (2000b, p.28) asserts that "Inflation targeting is equivalent to pegging the currency to a basket of goods." This is true of strict inflation targeting but not of its flexible counterpart.

${ }^{13}$ The language here is from Svensson (1999). Other authors refer to this as the distinction between policy objectives and policy rules.

${ }^{14}$ And where outcomes are uncertain. There is a growing literature on inflation targeting under uncertainty (for example, Levin, Weiland and Williams 1999, Kumhof 2000), which I leave aside in this paper. 
central bank's pants, inflation-forecast targeting, and the Taylor rule. I consider these alternatives in turn.

Seat-of-the-pants inflation targeting (using everything from in-house econometric models to central banker's intuition to guide the setting of policy instruments) is what many central banks do -- some with considerable success. But it is unlikely to be efficient insofar as it is not systematized. And to the extent that the rationale for the central bank's decision cannot be fully articulated and defended, it will lack credibility. ${ }^{15}$

Targeting the central bank's inflation forecast (conditional on the information available at the time of the forecast) is an example of an "intermediate targeting rule" that specifies a vector of intermediate targets that are correlated with the ultimate policy goal but easier to control and observe than the ultimate goal (Svensson 1999). Inflation forecast targeting should be more efficient than formulating policy on the basis of an ad hoc reaction function insofar as the policy instruments respond to all the information that is relevant to the forecast. It will have more credibility than the alternatives if the central bank has a track record of accurate forecasting. ${ }^{16}$

That seat-of-the-pants inflation targeting is arbitrary and that inflation-forecast targeting is no more reliable than the forecast have motivated the search for simple rules. The Taylor rule is the leading example. Taylor (1993) specifies a reaction function for a closed economy with

\footnotetext{
${ }^{15}$ Something that is likely to be particularly problematic in emerging markets, as I analyze below.

${ }^{16}$ This is another big if, and it is something that is likely to be especially problematic in emerging markets (as I discuss below). In addition, simply targeting the inflation forecast does not solve the problem that additional information about the structure of the economy and its reaction to policy is needed to inform the central bank's decision of how quickly to eliminate any discrepancy between the inflation forecast and the inflation target.
} 
positive weights on deviations from target inflation and from the natural rate of unemployment that closely tracks the actual policies followed by many central banks that target low inflation. Contributors to the closed-economy literature have shown how a Taylor rule can be derived as the optimal reaction function for a strictly inflation-targeting central bank. Let the economy be represented as:

$$
\begin{aligned}
& \pi_{\tau+1}=\pi_{\tau}+\alpha\left(y_{t}-y^{*}\right)+\varepsilon_{t+1} \\
& y_{t+1}-y^{*}=\lambda\left(y_{t}-y^{*}\right)-\beta\left(r_{t}-r^{*}\right)+n_{t+1}
\end{aligned}
$$

Equation (1) is an accelerationist Phillips Curve, where the change in inflation $(\pi)$ between this period and next is a function of this period's gap between actual output (y) and its natural level $\left(\mathrm{y}^{*}\right)$ and of a disturbance (denoted $\varepsilon_{\mathrm{t}+1}$ ). Equation (2) is aggregate demand, where next period's output gap is a function of this period's output gap, the deviation of the interest rate (r) from normal $\left(\mathrm{r}^{*}\right)$, and a disturbance $\left(\mathrm{n}_{\mathrm{t}+1}\right)$. The key assumption is that the control lag until inflation responds to the central bank's instrument ( $\mathrm{r}$ ) is longer than the control lag for aggregate demand (equivalently in the present context, that policy affects inflation only through the aggregatedemand channel).

Under strict inflation targeting, the optimal policy is to target inflation two periods ahead, setting $\pi_{\mathrm{t}+2}=\pi *$, where $\pi *$ denotes target inflation. (Inflation one period ahead is given by output in the current period, which is predetermined; hence inflation one period ahead cannot be controlled.) To solve for the optimal reaction function, shift equation (1) forward, substitute in (2), and set $\pi_{t+2}$ (the two-year inflation forecast) equal to $\pi *$ (thus adopting a version of inflation- 
forecast targeting). This yields:

$$
\mathrm{r}_{\mathrm{t}}=\mathrm{r}^{*}+\phi\left(\pi_{\mathrm{t}}-\pi *\right)+\chi\left(\mathrm{y}_{\mathrm{t}}-\mathrm{y}^{*}\right)
$$

This is a Taylor rule with positive weights on deviations of inflation from target and of output from its natural rate, where the weights $\phi$ and $\chi$ depend on the parameters $\alpha, \lambda$, and $\beta$. We see the point mentioned above, that even under strict inflation targeting there is still a positive weight on output in the reaction function because of its information content for future inflation.

However, equation (3) is a peculiar Taylor rule. Strict inflation targeting implies sharp changes in the interest rate in response to deviations of inflation from target and output from its natural level, since $\phi=1 /(\alpha \beta)$ and $\chi=(1+\lambda) / \beta .{ }^{17}$ For example, if $\lambda=0.8, \alpha=0.4$, and $\beta=0.6$, values that approximate realistic conditions, then we would observe changes in the interest rate in response deviations to both variables of several times the magnitude suggested by Taylor as matching the actual behavior of central banks. ${ }^{18}$ This in turn implies very considerable output fluctuations. It is worth emphasizing that we obtain this solution only because we are assuming that the central bank cares exclusively about inflation to the total disregard of output. This is a further indication, if one was needed, that central banks are not strict inflation targeters; they care also about the behavior of other variables.

${ }^{17}$ In the general case where the central bank cares not just about inflation but also about other variables like output, the reaction coefficients will also depend on the parameters of its objective function (see below). But that is not the case here.

${ }^{18}$ Taylor identifies $\phi=1.5$ and $\chi=0.5$ as replicating the actual behavior of inflationtargeting central banks. Here we get $\phi \cong 4$ and $\chi=3$. 
If it cares about the deviations of output from the natural rate as well as deviations of inflation from target, then an optimizing central bank, instead of adjusting two-year-ahead expected inflation all the way to the inflation target, will adjust it part way:

$$
\mathrm{E}\left(\pi_{\tau+2}\right)=\kappa \pi *+(1-\kappa) \mathrm{E}\left(\pi_{\tau+1}\right)
$$

where $\kappa$ is a constant between zero and one, and E denotes an expectation. Svensson (1996) derives this relationship in the present model and shows that $\mathrm{K}$ will be a decreasing function of the weight on output stabilization in the central bank's objective function. ${ }^{19}$

Life is more complicated if the structure of the economy is more complex -- for example, if the economy is open. It is to the complications that arise in the case of open-economy inflation targeting that I now turn.

${ }^{19}$ Similarly, the higher the central bank's discount rate (the more it cares about the present relative to the future) and the less responsive is inflation to output fluctuations (the smaller $\alpha$ ), the less will be the weight on target inflation. If inflation two periods ahead is of less concern (because the discount rate is higher), then the central bank will be prepared to incur less output variability in order to stabilize it. And if output has to be pushed around a lot in order to hit the inflation target, then the weight on that target in the reaction function will be less. These relationships are easy to show for shocks to $\varepsilon_{t}$ when the control lag from the policy instrument to inflation is only one period -- if we rewrite equation (2) as $\left.y_{t}-y^{*}=-\beta\left(r_{t}-r^{*}\right)+n_{t}\right)$ for example, so that the interest rate affects output immediately but inflation only with a one period lag -- but harder to show in the model in the text (again, however, see Svensson 1996). In contrast to the response to shocks to $\varepsilon$, in the variant in this footnote the interest rate is adjusted immediately in response to shocks to aggregate demand (to $n_{t}$ ), so as to return both inflation to target and output instantaneously to the natural rate; equation (4) in the text is irrelevant. 


\section{What's Different About Open Economies?}

The openness of emerging markets raises obvious questions about the relevance of the simple closed-economy inflation targeting framework. Openness exposes the economy to foreign shocks to both commodity and financial markets and introduces additional channels for policy. For example, the central bank's policy instrument (r) will now affect output not just directly, as in equation (2), but also indirectly through its impact on the exchange rate. While the direct interest-rate channel will dampen investment, as in a closed economy, the indirect channel will reduce net export demand by appreciating the exchange rate. This is easiest to see by starting from the interest parity condition that will hold in a financially open economy:

$$
e_{t}-E\left(e_{t+1}\right)=r_{t}-r^{\prime}+v_{t}
$$

where the exchange rate e is defined as the foreign price of domestic currency (an increase is an appreciation), $r$ ' is the foreign interest rate, and $v$ is a financial market (or "pure portfolio") disturbance. ${ }^{20}$ Ball (1999) and Mishkin and Savastano (2000) consider a simplified version of this relationship where the expected future exchange rate is constant (so that $\left.e_{t}=r_{t}-r^{\prime}+v_{t}\right) .^{21}$

${ }^{20}$ This is a "pure portfolio disturbance" in the sense that it appears only in this condition for financial market equilibrium, not also in the aggregate demand equation. Later in the paper I introduce an international commodity market (or "export market") disturbance that affects financial and commodity markets simultaneously. The implications for policy turn out to be rather different.

${ }^{21}$ One can attempt to justify this by arguing that since the expected values of the disturbances to equations (1) and (2) are zero, the exchange rate is expected to return to its (constant) level in the long run. But this ignores the distinction between temporary and permanent disturbances and between the long-run equilibrium level and the level one period out. 
For convenience, I adopt this simplification in what follows. The additional impact of the interest rate on output, operating through the exchange rate, then implies nothing more than a larger coefficient on the domestic interest rate in equation (2). Since it is assumed (for the time being) that the exchange rate and the interest rate affect the change in output with the same lag, (2) can be written as:

$$
\mathrm{y}_{\mathrm{t}+1}-\mathrm{y}^{*}=\lambda\left(\mathrm{y}_{\mathrm{t}}-\mathrm{y}^{*}\right)-\beta\left(\mathrm{r}_{\mathrm{t}}-\mathrm{r}^{*}\right)-\delta \mathrm{e}_{\mathrm{t}}+\mathrm{n}_{\mathrm{t}+1}
$$

Note that $\beta\left(r_{t}-r^{*}\right)+\delta e_{t}=(\beta+\delta) r_{t}-\beta r^{*}$. In open economies where the output response is larger, adjustments in the policy instruments will be smaller. But the reaction function is otherwise unchanged.

The implications are more complex if exchange rate movements also affect inflation directly with the same one-period lag as it is affected by the output gap. ${ }^{22}$ In other words, we rewrite equation (1) as:

$$
\pi_{\tau+1}=\pi_{\tau}+\alpha\left(y_{t}-y^{*}\right)-\gamma\left(e_{t}-e_{t-1}\right)+\varepsilon_{t}
$$

Strict inflation targeting is the simple case as always. Now a central bank that wishes to hit its

${ }^{22}$ In the model of the previous section, the policy instrument could affect inflation only after two periods, since there was a one-period lag from policy to the output gap and a further one-period lag from the output gap to inflation. Ted Truman has raised the question (in private correspondence) of whether there is strong empirical support for this assumption that the impact of monetary policy on inflation is felt faster in open economies. 
inflation target in $\mathrm{t}+1$ and not just $\mathrm{t}+2$ can do so. It does this by using its instrument (the interest rate) to alter the exchange rate and hence import prices. But output is more variable than before, since the interest rate is no longer adjusted to push output back toward its natural level (that having been the only channel, in the closed economy, through which policy could affect inflation in the event of an aggregate demand shock). Thus, strict inflation targeting that puts a high weight on inflation stability will result in more output instability in an open economy. ${ }^{23}$

Intuition suggests that when the central bank values the stability of both inflation and output, the ratio of the two reaction function coefficients (the response to inflation deviations relative to the response to output deviations, that is, the ratio $\phi$ to $\chi$ in equation 3 above) will be smaller in more open economies. ${ }^{24}$ In terms of equation (4), the central bank will move more slowly to restore inflation to its target level ( $\kappa$ will be smaller). Because the policy instrument, operating through the exchange rate, has a more powerful first-period effect on inflation, tending to destabilize output as well as stabilizing inflation, policy is used more moderately in response

\footnotetext{
${ }^{23}$ Note that it is current account openness as well as financial openness that matters for this conclusion.

${ }^{24}$ While a closed-form solution demonstrating this result is not available, Ball (1999, pp.132-133) obtains it in a simulation of the present model. Gomez (2000) conducts analogous exercises using the more elaborate model in Svensson (2000). For flexible CPI inflation targeting (the case relevant to the present discussion), he obtains this result over most of the relevant range: as the share of imported goods in the CPI rises from, say, 10 to 50 per cent, the reaction to innovations in domestic inflation declines relative to the reaction to output innovations. However, as openness begins to rise from very low levels, the reaction to inflation innovations falls relative to the reaction to output innovations. Since an increase in the share of imported goods affects several parameters of Svensson's model (notably the effects of both the exchange rate and the output gap on inflation and effect of the exchange rate in the Phillips Curve) in interdependent nonlinear ways, it is not surprising that the change in the ratio of the two reaction function coefficients is not the same over the entire range of possible values for openness.
} 
to a given ratio of deviations of inflation to deviations in output.

An open economy is susceptible to shocks emanating from international commodity and financial markets. Although both types of shocks will affect the exchange rate, the appropriate policy response by an inflation-targeting central bank will depend on the source. Consider first a shock emanating from financial markets -- a change in the direction or availability of capital flows due to, say, a rise in world interest rates (or a deterioration in foreign investor sentiment toward the country). I refer to this in what follows as "Calvo shock." 25 This can be modeled as an increase in $\mathrm{r}^{\prime}$ ( or as a low realization of $v$ ). A higher foreign interest rate implies less capital inflow for a given domestic interest rate and therefore a weaker currency, ceteris paribus. As the exchange rate weakens, higher import prices are passed through into inflation. ${ }^{26}$ The optimal response is then to raise interest rates.

Note that this encourages "fear-of-floating" type behavior by an inflation targeting central bank (although the exchange rate may still be considerably more flexible than if it is pegged). If a Calvo shock displaces the exchange rate, then the interest rate adjustments that offset the inflationary consequences have the effect of moderating the change in the value of the currency (of bringing the exchange rate back toward its previous level). If the currency weakens, the central bank raises interest rates, which strengthens it, ceteris paribus. If it strengthens, the

\footnotetext{
${ }^{25}$ Guillermo Calvo having emphasized the impact of capital-flow-related shocks to emerging markets.

${ }^{26}$ The weaker exchange rate also implies future inflation insofar as it boosts export demand, but this is a secondary effect. That a decline in capital inflows would raise aggregate demand seems peculiar; it is a figment of the present thought experiment because the domestic interest rate (the other main determinant of aggregate demand) is held constant. The paradox is dissolved by the next sentence in the text.
} 
central bank reduces rates, which weakens it, other things equal. This is not because the central bank cares about the exchange rate in and of itself but because it cares about inflation.

However, while a central bank confronted by a Calvo shock will raise interest rates in order to moderate the depreciation of the currency, it will not prevent the exchange rate from moving, as the strong "fear of floating" view would suggest. Higher interest rates imply weaker domestic demand in the new long-run equilibrium, and that decline in domestic demand will have to be offset by additional export demand created by a weaker exchange rate. Thus, while the degree of exchange rate flexibility will be limited by central bank policy, such flexibility will not be eliminated entirely. The currency will still exhibit greater flexibility than when it is pegged.

The intuition that central banks concerned about future inflation should adjust the interest rate to counter fluctuations in the exchange rate has been formalized as the idea of a "monetary conditions index." The MCI, which indicates the overall stance of policy, is a weighted average of the interest rate and the exchange rate (since these two variables are linked by equation 5) where the former is adjusted to offset finance-induced fluctuations in the latter. ${ }^{27}$ Using a simulation model of the New Zealand economy, Hunt (1999) shows that when the main source of

\footnotetext{
${ }^{27}$ Freedman (1994) has suggested that the weights in the composite indicator made up of the interest rate and the exchange rate (the "monetary conditions indicator") should be proportional to the coefficients on e and $r$ in the Phillips Curve (equation 2' above). That is, they should be proportional to the parameters $\beta$ and $\delta$ above. For representative parameter values, this means that when the exchange rate depreciates by 1 per cent, holding everything else constant, the interest rate has to be raised by some 30 basis points to damp down growth and the domestic inflation that it provokes. (In constructing this example I assume that it is the log exchange rate but the level of the interest rate that enter equation $2^{\prime}$.) In reality, the optimal response depends on more than simply these two parameters, as should now be clear, but Ball (1999) shows that Freedman's intuition is basically correct: that the weights coefficients are likely to be fairly close to the ratio of coefficients on the exchange rate and the interest rate in the Phillips curve.
} 
shocks is from international financial markets to the exchange rate, it will be desirable to target an MCI which includes both the interest rate and the exchange rate (raising interest rates when the exchange rate weakens, other things equal).

What if the shock is temporary? A transitory shock to $v$ that depreciates the exchange rate will still dictate a limited rise in interest rates to damp down future demand-induced inflation. ${ }^{28}$ But because the direct impact on inflation through higher import prices is transitory, responding to it with sharply higher interest rates will only amplify the volatility of output and inflation, since $v$, and with it underlying inflationary pressures, will have returned to normal in the next period. Interest rates should be hiked to damp down only the domestic component of inflation (which derives from the persistent increase in aggregate demand), but not also the contribution of imported inflation (which is temporary). Responding this period to a problem that will have disappeared by next period, using an instrument that takes one period to work, will only produce cycles of output and inflation.

In Ball's (1999) model, the implication is that the monetary conditions indicator (the weighted average of the interest rate and the exchange rate) should be adjusted not to movements in $\pi_{t}$ but to movements in $\pi_{t}+\gamma\left(e_{t}-e_{t-1}\right)$, where $\gamma$ is the response of inflation to a change in the exchange rate. In other words, the authorities should target domestic inflation and not CPI inflation. Bharucha and Kent (1998) use a simulation model of Australia to show that responding only to the domestic component of inflation (and not also to imported inflation)

\footnotetext{
${ }^{28}$ Under the assumption that even temporary shocks to the foreign exchange market have persistent output effects, as will be the case given the structure of equation 2 '.
} 
delivers better results when shocks to the exchange rate are temporary. ${ }^{29}$ Since the interest rate response to movements in the exchange rate will be less, fear-of-floating type behavior will be less when capital market shocks are temporary. ${ }^{30}$

All this rests on the assumption that the source of disturbances is international financial markets. Assume instead that the disturbance is to the foreign component of aggregate demand (to the terms of trade or to export demand). I refer to this as a "Prebisch shock." The exchange rate will again weaken, since export revenues will have declined while nothing else affecting the foreign exchange market will have changed in the first instance. In addition, aggregate demand will weaken, since foreigners are demanding fewer of the country's exports. ${ }^{31}$ Now there are two

\footnotetext{
${ }^{29}$ Ryan and Thompson (2000) suggest that it may not be necessary to explicitly target the domestic price index if the CPI target is defined as an interval rather than a point. They argue that Australia's monetary policy framework deals with this problem by permitting relatively small divergences from the 2-3 per cent target band over the cycle "provided inflation is forecast to be back within 2-3 per cent in the medium term. The forward-looking nature of policy should also be sufficient to prevent the RBA from responding to exchange rate shocks which are only expected to have a temporary effect on inflation" (p.2).

${ }^{30}$ It may seem peculiar that the central bank will intervene less to neutralize transitory shocks to the foreign exchange market (which standard efficiency arguments suggest it might want to obviate) than in response to long-lived shocks. The result reflects the existence of control lags between monetary policy on the one hand and inflation and output on the other; in this setup, responding as vigorously to a purely temporary shock as to a permanent shock just destabilizes the target variables.

${ }^{31}$ We can model this by adding the commodity market disturbance $\mu$ to the exchange-rate and aggregate-demand relationships (5) and (2'). The former becomes:

$$
e_{t}-E\left(e_{t+1}\right)=r_{t}-r^{\prime}+v_{t}+\mu_{t}
$$

while the latter becomes:

$$
\mathrm{y}_{\mathrm{t}+1}-\mathrm{y}^{*}=\lambda\left(\mathrm{y}_{\mathrm{t}}-\mathrm{y}^{*}\right)-\beta\left(\mathrm{r}_{\mathrm{t}}-\mathrm{r}^{*}\right)-\delta \mathrm{e}_{\mathrm{t}}+\xi \mu_{\mathrm{t}}+\mathrm{n}_{\mathrm{t}+1}
$$

where $\xi$ is a parameter linking the terms-of-trade shock to aggregate demand. (The export- 
offsetting effects on inflation: while higher import prices will be passed through into inflation, weaker aggregate demand will be deflationary.

In the real world the first effect is likely to dominate. ${ }^{32}$ If the central bank attaches a high weight to output variability, it may still hesitate to raise interest rates, knowing that inflation will decline subsequently due to the weakness of output. If, as is more typically the case, it attaches a high weight to deviations of inflation from target, it will raise interest rates to limit currency depreciation in the short run, while still allowing the exchange rate to adjust eventually to its new long-run equilibrium level. While it will lean against the wind, it will not prevent the exchange rate from moving. It will not display fear of floating in this strong sense..

Note that the monetary conditions indicator now sends the wrong signal in response to this shock. It suggests raising interest rates to counter the weakness of the exchange rate, where the appropriate response is to allow the exchange rate to move down to a lower long-run equilibrium level to offset the negative real shock. Mishkin (2000) cites cases (such as New Zealand in 1997 and Chile in 1998) where the central bank either utilized a monetary conditions indicator or attempted to limit the variability of the exchange rate as part of its inflation targeting regime, inducing precisely the wrong response to a shock to external demand (tightening when

demand shock is assumed to affect output with the same lag as movements in the exchange rate emanating from other sources.)

${ }^{32}$ Otherwise, inflation will decline with the growth in the gap between potential and current output. The appropriate response for an inflation-targeting central bank is to cut interest rates, regardless of the weight it attaches to output variability. Now central bank behavior will not resemble fear of floating. To the contrary, the cut in interest rates will accentuate the change in the value of the currency. Because the decline in foreign demand requires a weaker exchange rate in order to stabilize output (and because the cut in demand also subdues inflation), the central bank does nothing to limit the adjustment of the exchange rate; to the contrary, it encourages it to adjust. 
the economy was weakening).

To summarize, inflation targeting is more complicated in open economies, reflecting the additional shocks to which such economies are exposed and the additional channels linking policy instruments and outcomes. Insofar as policy has more powerful effects when it operates through the exchange rate as well as the interest rate, this implies, other things equal, that policy instruments should be adjusted less in response to the same shocks. Insofar as the additional exchange rate channel linking interest rates to inflation changes the structure of policy lags, openness also requires rethinking the relative weights on inflation and output in the reaction function. In general, the central bank of an open economy will respond less to inflation deviations relative to output deviations, since monetary policy, which also operates through the exchange rate, now has a more powerful, immediate effect on inflation.

Will open-economy inflation targeters exhibit "fear of floating?" In general, an inflation targeting central bank will let the exchange rate adjust, although it may wish to smooth its movement. It will lean against the exchange rate change in response to shocks. If the exchange rate depreciates, it will raise the interest rate. But it will not prevent the exchange rate from adjusting to a new long-run equilibrium level. It will not display fear of floating in this strong sense.

\section{What's Different About Emerging Markets?}

What is different about emerging markets is the speed of passthrough, the difficulty of forecasting inflation, liability dollarization, and credibility issues.

\section{A. Higher Passthrough}


Calvo and Reinhart provide evidence that changes in import prices due to movements in the exchange rate are passed through into domestic prices faster in emerging markets than industrial countries. A history of inflation may have raised agents' awareness of and sensitivity to imported inflation and led to formal indexation. The commitment to price stability may lack credibility; hence, it may be feared that transitory shocks leading to depreciation of the exchange rate will be validated by policy and hence become permanent. ${ }^{33}$

Faster passthrough can be formalized as a larger $\gamma$ and a smaller (absolute value of) $\delta$ in equation (1'). With high passthrough, a change in the exchange rate has a large short-run impact on inflation and a small short-run impact on output. If there is a shock to the foreign exchange market (a negative Prebisch shock, for example, that causes the rate to depreciate and output to fall), the authorities will have less reluctance to tighten than in the case of slower passthrough, since they gain more in terms of disinflation as the currency stabilizes and strengthens, while losing less as output falls due to declining competitiveness.

But the preceding paragraph makes clear that passthrough is not an exogenous parameter that can be regarded as independent of the monetary regime. If the credibility of the commitment to low inflation is enhanced by an institutionalized commitment to price stability, central bank independence and accountability, and policies of communicating the rationale for monetarypolicy decisions, then agents will revise downward the likelihood they attach to the prospect that transitory shocks will be validated by policy and hence become permanent, and therefore how

\footnotetext{
${ }^{33}$ The sources and further implications of limited credibility are left to Subsection D below.
} 
quickly they adjust prices in response to a weaker exchange rate. ${ }^{34}$

Under full (instantaneous, 100 per cent) indexation, monetary policy has no capacity to stabilize -- or, for that matter, destabilize -- output. ${ }^{35}$ It can simply be used to target inflation. With full indexation, that target can be hit immediately. ${ }^{36}$ Full indexation thus simplifies the inflation targeting problem since it reduces the central bank's objective function to the one variable that it can now influence and allows the authorities to hit that target immediately. ${ }^{37}$

The implications for exchange rate management depend on the source of shocks. If domestic monetary policy is the source of the instability, then stabilizing the exchange rate will force the central bank to undo such shocks immediately. If shocks are external, then the exchange rate should adjusted to offset them. Foreign deflation will induce an inflation-targeting central bank to expand the money supply and allow the currency to depreciate, while an inflationary shock will induce the opposite reaction..$^{38}$ Thus, while rapid passthrough will modify the implementation of monetary policy by an inflation targeting central bank, it is not a fundamental challenge to the viability of that approach to its formulation.

\section{B. Difficulty of Forecasting Inflation}

${ }^{34}$ There is some anecdotal evidence of this for Brazil and Mexico (Mishkin and Savastano 2000) and Israel (Leiderman and Bufman 2001).

${ }^{35}$ See Sachs (1980).

${ }^{36}$ This is note to say that central bankers in fully indexed economies have necessarily had particular success in hitting that target, especially in those countries where fiscal deficits are chronic and central bank independence is limited.

${ }^{37}$ This is just the limiting case of the thought experiment described at the beginning of the previous paragraph.

${ }^{38}$ We are in what Calvo (2000b) refers to as the world of the traditional model. 
Disturbances make it difficult for observers to evaluate the central bank's commitment to inflation targeting, since it is often hard to determine the extent to which divergences between actual inflation and the target are due to the monetary policy implemented several quarters ago as opposed to shocks occurring during the control lag. This uncertainty may reduce credibility -- it will not be clear whether the central bank is in fact following the announced policy. ${ }^{39}$ This is where the conditional inflation forecast comes in. ${ }^{40}$ The central bank announces a point or range forecast for inflation and explains how its instrument settings are consistent with its forecast. If it misses the target, it must then be able to point to unanticipated disturbances occurring during the control lag that can account for the discrepancy or risk losing credibility.

If reliable forecasting is not possible, then the markets may be unable to determine the intent of the authorities. A brutally-honest central bank might surround its point forecast with a wide confidence interval. But a wide range of outcomes will be consistent with a wide range of policies, complicating efforts to determine the authorities' intent. Nor will specifying a narrow forecast range and missing it repeatedly build confidence in the central bank's commitment to its target.

Forecasts based on historical relationships can be invalidated when there is a change in the policy process -- that is to say, a change in the monetary regime. And what is the adoption of formal inflation targeting but a change in regime? Thus, the problem of forecasting inflation in the early phases of the new regime is general, not specific to emerging markets. But there are

${ }^{39}$ See below.

${ }^{40}$ As noted above, this can be interpreted as minimizing the loss function using all the relevant information. This should be the central bank's internal forecast and not a market forecast to avoid problems of multiple equilibria. 
reasons to worry that it is especially difficult there. Emerging markets attracted to inflation targeting will typically be bringing down inflation from high levels. Thus, the change in regime is likely to be particular sharp and inflation volatility particularly pronounced during the transition. Passthrough may change. De-indexation will be proceeding with uncertain consequences. The shift from an alternative monetary policy operating strategy to inflation targeting will be part of a package of stabilization measures, typically including structural reforms of the public and private sectors that transform the inflation process in unpredictable ways. If the country is emerging from a period of strict central planning, price controls may be in the process of elimination, and there may be the prospect of sharp changes in excise taxes to augment public-sector revenues and enhance the efficiency of tax collection.

While these are reasons why inflation forecasting may be especially difficult during the transition, they do not obviously challenge its feasibility once the aforementioned structural and policy reforms have been put in place. Revealingly, those emerging markets that have adopted full-fledged inflation targeting have not generally started from a position of high inflation; rather, they have first brought inflation down to moderate levels and pursued other reforms before installing the new regime. ${ }^{41}$

But are there also structural features of emerging markets that complicate the forecasting exercise even once these reforms are complete? Emerging economies are more commodity-price sensitive than their advanced-industrial counterparts, and commodity-price fluctuations can wreak havoc with the forecastability of consumer price inflation. There is the fact that

\footnotetext{
${ }^{41}$ The point applies to Brazil, for example, which had considerable success in moderating inflation between 1994 and 1998.
} 
foodstuffs, whose prices are affected by the weather, have a heavy weight in the CPI in lowincome countries. The obvious solution to both problems is to target "core" (or underlying) inflation net of commodity prices, as is the practice of some industrial countries. ${ }^{42}$

Then there is such countries' disproportionate dependence on capital flows. Sensitivity of domestic financial conditions to international capital flows is, in a sense, the defining feature of an emerging market. The literature on asymmetric information suggests that unpredictable volatility is especially pronounced in the financial sphere, and nowhere more than in international financial markets. Because information is costly to acquire and process, investors are imperfectly informed. They therefore herd in and out of markets in response to the movements of other investors, amplifying volatility. Because asymmetric information reduces the liquidity of financial assets in periods of distress (reflecting fears that assets liquidated in fire sales are damaged goods), illiquidity and balance-sheet problems may transmit financial difficulties across borders, with destabilizing repercussions for innocent bystanders. ${ }^{43}$ These phenomena will be most pronounced in international markets, where information must travel geographical and cultural distance, and in emerging markets, where the information environment is least developed.

The forecastability of inflation, ultimately, is an empirical issue. Hoffmaister (1999) has analyzed it in South Korea, finding that inflation is roughly as forecastable there as in Sweden. Univariate models of inflation perform similarly in Korea and in the high-income inflation

\footnotetext{
${ }^{42}$ There are likely to be credibility issues here as well. Again I defer these to a subsequent subsection.

${ }^{43}$ The now extensive literature on contagion is concerned with this point.
} 
targeters in the period immediately preceding their adoption of the strategy, although there is some evidence of positive kurtosis, as if inflation is subject more frequently to larger shocks than would be expected given its standard deviation. Christoffersen and Wescott (1999) and Rivas (2001) similarly find evidence of kurtosis and skewness for Poland in 1992-98 and Nicaragua in 1988-98, respectively. But upon eliminating some of the largest and smallest price changes each month among the 33 main categories in Poland's CPI to derive a measure of core inflation, Christoffersen and Wescott find that a limited set of economic variables forecasts one-periodahead core inflation reasonably well by international standards. ${ }^{44}$ Rivas similarly has considerable success in forecasting core inflation in Nicaragua so long as he focuses on the period of moderate inflation starting around 1993.

Thus, the difficulty of forecasting inflation may be an obstacle to effective inflation targeting in an economy in economic and financial disequilibrium. It is not realistic to hope to forecast inflation with the requisite reliability if the country is still bringing inflation down from high levels, comprehensively reforming the tax and public-spending systems, and radically restructuring the private sector. But where such reforms have been underway for some time and are proceeding at a measured pace -- as in Poland, South Korea and Brazil -- forecasting difficulties would not appear to be an insurmountable obstacle to inflation targeting.

\section{Liability Dollarization}

In many emerging markets, the obligations of banks, corporations and governments -their foreign obligations in particular -- are denominated in foreign currency, while their revenues

\footnotetext{
${ }^{44}$ Since their measure of core inflation is constructed transparently, this should be something that private agents are able to replicate.
} 
are domestic-currency denominated to a considerable extent. Insofar as banks and other intermediaries close their open foreign-currency positions by issuing dollar-denominated loans, they will simply pass on that problem of liability dollarization to their customers. When the exchange rate depreciates, their balance sheets will still suffer, and this "financial accelerator" will depress output and employment.

The simplest way of thinking about liability dollarization is as reducing $\delta$, the positive response of output to currency depreciation in equation (2'). While depreciation renders domestic goods more competitive, as before, it now also weakens the balance sheets of banks, firms, households and governments, depressing consumption and investment. The second effect partially offsets the first. ${ }^{45}$

Consider the response to a Calvo shock, compared to the benchmark case analyzed in Section 2. Weaker consumption and investment due to adverse balance-sheet effects now imply less inflation in the intermediate run than before. An inflation-targeting central bank will therefore feel less compelled to raise interest rates in order to push up the exchange rate and damp down the increase in import prices. ${ }^{46}$ If the shock to the exchange rate instead emanates from commodity markets (a negative Prebisch shock), higher import prices will still be passed through into inflation, but now aggregate demand will be weaker than before because of the adverse balance-sheet effects. Since output is lower and inflation is no higher than in the absence

\footnotetext{
${ }^{45}$ It turns out that this is not precisely what those concerned with the perverse effect of exchange rate changes in the presence of liability dollarization have in mind, as I explain momentarily.

${ }^{46} \mathrm{We}$ can also see this from Freedman's formulation of the monetary conditions indicator and from Ball's model, where the weight on the exchange rate in the MEI declines with $\delta$.
} 
of liability dollarization, again there will be less pressure to hike interest rates in order to stabilize the currency and damp down inflation, and more incentive to cut interest rates to stimulate production (compared to the situation where balance-sheet effects are absent). This suggests that, regardless of the source of shocks, "fear of floating" will be less in the presence of liability dollarization. ${ }^{47}$

While this may seem counterintuitive, it is simply an illustration of the general point that when the central bank worries more about variables other than inflation, either because of a heavier weight on those variables in its objective function, or because the parameters of the model cause those other variables to be displaced further from their equilibrium levels (where the latter is the case presently under discussion), it will move more gradually to eliminate discrepancies between actual and target inflation. Because the exchange rate must move more to increase output and employment, and because measures which would limit its fluctuation and thereby reduce imported inflation tend to destabilize the real economy, the now weaker tendency for depreciation to stimulate activity means that the central bank will do even less to limit depreciation.

The same is true when the problem in the financial system is maturity mismatches rather than currency mismatches. (This can be modeled as an increase in the coefficient $\beta$ in the aggregate demand equation.) Again, the more the central bank fears that an interest rate hike designed to damp down inflation will cause financial distress (because the maturity of banks' liabilities is shorter than their assets, or because higher interest rates will increase default rates

\footnotetext{
${ }^{47}$ This is therefore what Cepedes, Chang and Velasco (2001), find in their simulation model of optimal monetary policies in the presence of liability dollarization.
} 
among bank borrowers), the less it will raise interest rates in the intermediate run to strengthen the exchange rate and limit inflation.

Clearly, those who argue that liability dollarization creates fear of floating have something else in mind, presumably that the balance-sheet effects of currency depreciation are so strong that they turn $\delta$ negative. Let $-\delta>\beta$, so that a cut in the interest rate which weakens the exchange rate depresses output on balance. This constellation of parameter values is extreme (and it has some peculiar implications, as we will see momentarily), but it would appear to be what the Cassandras of liability dollarization have in mind.

As before, a negative Calvo shock fuels inflation through higher import prices. It also now lowers output through the adverse balance-sheet effect. The appropriate response, which damps down inflation and stabilizes output by limiting balance-sheet damage, is to raise interest rates and push the exchange rate back up to its pre-shock level. ${ }^{48}$ "Fear-of-floating" type behavior results. If the disturbance is instead a Prebisch shock, the weaker exchange rate again means more imported inflation and lower levels of output. (The decline in output is even larger than in the comparable thought experiment in Section 2 because the direct effect of the decline in foreign demand is reinforced by the indirect effect of exchange rate depreciation via its adverse impact on balance sheets.) Again, interest rate hikes are the appropriate response to both problems, since a higher interest rate which strengthens the exchange rate not only damps down inflation but also strengthens balance sheets. Again, the central bank will not hesitate to raise

\footnotetext{
${ }^{48} \mathrm{Here}$ it is important to interpret e as the real exchange rate and $\mathrm{r}$ as the real interest rate, since even temporary depreciation will lead to inflation and a higher price level, whose implications for the real exchange rate are otherwise suppressed in this simple model by omitting that price level from the aggregate demand equation.
} 
interest rates. Again, its response will resemble fear of floating.

This formulation has some peculiar implications, as already noted. For one, a negative shock that reduces export demand and depresses output must be offset in the new long-run equilibrium by an appreciated exchange rate, not a depreciated one. ${ }^{49}$ In this peculiar world, overvaluation is good for output because its favorable financial effects dominate its adverse competitiveness effects. It can be reasonably objected that this is unrealistic -- that it is implausible to assume that $-\delta>\beta$. But relaxing this assumption means we are back in a world not just where the authorities allow the exchange rate to adjust to a new lower level following an adverse Prebisch shock but also where they do not jack up interest rates to significantly slow its movement. In other words, we are back in the world where they display "fear of fixing" rather than "fear of floating."

A possible reconciliation is that when the exchange rate depreciates by a large amount, the adverse balance-sheet effects dominate, but when it depreciates by a small amount, the favorable competitiveness effects dominate. Large depreciations cause severe financial distress because they confront banks and firms with asset prices for which they are unprepared, while doing little to enhance competitiveness because of the speed with which they are passed through into inflation. For small depreciations, the balance of effects is the opposite; small depreciations are more likely therefore to satisfy the conditions for an expansionary devaluation. There is a range of exchange rates far from prior levels for which $-\delta>\beta$, in other words, and another range

${ }^{49}$ The same is now true of a negative Calvo shock: the tendency for higher (domestic and world) interest rates to depress output is offset by policies that push the exchange rate up and strengthen balance sheets. 
closer to prior levels where $-\delta<\beta .^{50}$ While this nonlinearity in the effect of the exchange rate on output might seem arbitrary, it is precisely the way authors like Aghion, Baccheta and Banerjee (1999) and Krugman (2001) model the interplay of competitiveness and balance-sheet effects: the former dominates for small depreciations but the latter dominate for large ones, producing a nonlinear aggregate equation of precisely the sort being assumed here.

If the exchange rate then falls sufficiently to enter the first range, an inflation-targeting central bank will raise interest rates sharply and push the currency up quickly in order to minimize financial damage to banks, firms and households. But if the depreciation is modest, so too will be the rise in interest rates; the central bank will allow the currency to fall to a new lower level so long as the competitiveness effects continue to dominate the balance-sheet effects. In fact, heavy intervention when the exchange rate drops precipitously but light intervention when it fluctuates around normal levels is not unlike the observed behavior of many central banks.

It is important to emphasize that liability dollarization, as analyzed here, in no sense precludes inflation targeting. The preceding propositions for how the central bank should respond flow directly from the standard inflation-targeting framework. But in the extreme case of liability dollarization where interest-rate cuts depress output as well as aggravating inflation (that is, where $-\delta>\beta$ ), that response will be such as to limit exchange rate variability. If the perceived advantage of inflation targeting is that it permits a greater exchange rate flexibility (compared to the alternative of a hard peg), then the advantages of inflation targeting are in practice correspondingly less in highly dollarized economies.

\footnotetext{
${ }^{50}$ If, for example, if default rates are not just proportional to the rate of currency depreciation but increase at an accelerating pace, this could plausibly be the case.
} 
This discussion assumes that the output effects of liability dollarization are independent of the policy regime. This assumption may be no more appropriate here than it is for passthrough and indexation. The greater exchange rate variability that the shift from pegging to inflation targeting implies, even if it is slight, will encourage hedging by banks and corporates. Whereas a policy of pegging the currency is tantamount to providing implicit insurance against currency risk, which discourages private purchases of currency hedges (why hedge when doing so is costly and the government avers its commitment to limiting currency fluctuations?), the knowledge that the exchange rate is allowed to move on a daily basis will strengthen the hand of a chief financial officer trying to convince his CEO of the importance of purchasing a hedge. Precisely those banks and corporates most vulnerable to financial distress because the liability side of their balance sheets is dollarized will have the greatest incentive to hedge. Even if banks and firms are unable to borrow abroad in their own currency in the aggregate, they will have an incentive to redistribute that foreign exposure in ways that limit the adverse output effects of depreciation. Thus, the adverse balance sheet effects that occur in a country that has traditionally oriented its monetary policy strategy around the level of the exchange rate may not be a good guide to the magnitude of these effects when the central bank shifts to an inflation targeting regime that implies even a modest increase in exchange rate flexibility. And even a modest increase in exchange rate flexibility that leads to a modest increase in hedging will make it optimal for an inflation-targeting central bank to allow a bit more exchange rate flexibility, which may encourage a bit more hedging, and so on. If the demand for unhedged dollar liabilities is endogenous, then behavior under the new regime -- by the central bank as well as the private sector -- may be quite different from behavior under the old one. 
What if this response is not forthcoming, perhaps because the relevant hedging instruments are not available? If the authorities are concerned that inflation targeting still looks too much like a de facto soft peg, rendering the country vulnerable to a build-up of speculative pressure, then it may be possible to fulfill the desire for greater flexibility only through the imposition of limits on gross and net foreign currency exposures. The regulatory authorities will have to limit the gross foreign-currency exposures of the banking system (and strengthen corporate governance and prudential practices in the financial sector so as to encourage banks to better manage and limit those exposures on their own). The central government will have to limit its foreign-currency borrowing to the extent that its domestic-currency-denominated revenues are imperfectly indexed to the exchange rate, and it should similarly takes steps to discourage excessive foreign-currency borrowing by states and municipalities.

Such measures are in fact integral to the agenda pursued by G-7 governments and the multilaterals under the umbrella of the "new international financial architecture." Greater exchange rate flexibility has also been an element of this agenda. ${ }^{51}$ But if this ability to regulate markets (and for markets to regulate themselves) is beyond the capacity of an emerging economy, then evasion and regulatory laxity will result in destabilizing balance-sheet effects, undermining the viability of an inflation targeting regime that aspires to permit increased exchange rate flexibility. It is revealing that those emerging markets which have moved to inflation targeting and have succeeded in achieving greater de facto exchange rate flexibility have generally had relatively well-developed financial systems and regulatory capacity.

One can question whether the solution is worth the price. If the exchange rate

\footnotetext{
${ }^{51}$ In either a rare instance of internal consistency or a fortuitous coincidence.
} 
movements implied by inflation targeting are compatible with financial instability only when foreign borrowing is curtailed, then the cost may be slow growth and underdevelopment. The severity of this risk depends on one's evaluation of the importance of foreign capital for domestic development and of the extent to which gross (as opposed to net) exposures must be curtailed to reconcile exchange rate flexibility with financial stability. Those fearful that curtailing capital flows will hinder growth logically prefer full dollarization.

\section{Credibility Problems}

We have already seen how the difficulty of forecasting inflation can lessen the credibility of inflation targeting in emerging markets (although I have argued that the point should not be pushed too far). In addition, a history of arbitrary enforcement that lessens respect for constitutional and statutory law may limit the effective independence of the central bank, whose insulation from pressure to pump up activity before an election or to help meet the government's financial needs is a prerequisite for effective inflation targeting. Central bankers threatened with dismissal, notwithstanding laws ostensibly guaranteeing them long terms in office, will be more inclined to bow to pressure to purchase government securities on the primary market. And chronic budget deficits can convince even an independent central bank that it has no choice but to meet the government's fiscal needs if it wishes to preserve financial stability, sowing the seeds of time inconsistency. ${ }^{52}$

\footnotetext{
${ }^{52}$ It is revealing that emerging markets have generally introduced full-fledged inflation targeting only after first attaining strong fiscal positions. See Schoechter, Stone and Zelmer (2000). Then there is the argument of whether inflation targeting is part of the solution to the problem of "fiscal dominance," as the time inconsistency problem created by chronic deficits is known. This is, of course, the same argument made by some advocates of hard pegs and is open to the same objections. I return to this point below.
} 
Historically, lack of effective central bank independence has been a major impediment to the pursuit of an independent monetary policy in developing countries. At the same time, emerging markets have come a long way in recent years in developing political support for low inflation and buttressing the independence of their central banks. ${ }^{53}$ Although budget deficits have been chronic problems, there has also been considerable progress in strengthening fiscal institutions and bringing down budget deficits. ${ }^{54}$ The dozen or so transition economies seeking membership in the EU and its monetary union, for example, have made very considerable progress in bringing their deficits and debts to within the Maastricht Treaty's 3 and 60 per cent ceilings.

To the extent that inflation targeting is less credible in emerging markets, its benefits will be less. Absent confidence that the central bank is committed to low inflation, interest rates will not fall to the levels of other low-inflation countries. Shocks will raise questions about whether the authorities are prepared to stay the course. Sharp changes in interest rates, exchange rates and international capital flows may feed upon themselves: financial variables will be volatile, with negative implications for the economy. If policy is not credible, then firms will not reduce price increases to meet the inflation target. Hitting it will require an increase in interest rates sufficient to deliver a substantial reduction in import prices (through a sharp appreciation of the exchange rate), with destabilizing output effects. ${ }^{55}$

${ }^{53} \mathrm{~A}$ comprehensive compendium of the relevant evidence is Mahadeva and Storne (2000).

${ }^{54}$ I say more on the reform of fiscal institutions below.

${ }^{55}$ The same negative implications also follow, of course, for any other monetary regime if the financial system is fragile, the commitment to fiscal discipline is questionable, the monetary authorities lack autonomy and independence, and the economy is subject to foreign disturbances. 
A wide variety of models of monetary policy point to the fact that there is a tradeoff between flexibility and credibility. Central banks most lacking in credibility will have an incentive to move along the frontier of feasible credibility-flexibility combinations in order to obtain it. In particular, imperfect credibility may require the central bank to target inflation rigidly. Absent credibility problems, a central bank faced with inflation in excess of its target may want to raise interest rates and damp down inflation only gradually in order to avoid causing or compounding a recession. Faced with a weak banking system ill prepared to absorb interest rate increases, which raise the cost of servicing its short-term liabilities and increase default rates by borrowers, it may want to limit interest-rate volatility and administer its anti-inflationary medicine in small doses. But if the monetary authorities fail to respond quickly when inflation heats up, observers may begin to wonder whether they are optimally trading off objectives or they are in fact not really committed to price stability. Asset prices and the variables they affect will not respond as hoped. Similarly, if the central bank targets core rather than headline inflation, observers may wonder whether this is because monetary policy should not attempt to offset temporary commodity price fluctuations, or whether the authorities are really just seeking an excuse to disregard inflationary pressures. ${ }^{56}$ Monetary policy will thus have to respond more sharply to exchange rate and commodity-price fluctuations than would be the case if it was being implemented by a highly credible central bank. The monetary authorities may not be able to afford even modest deviations from strict inflation targeting for fear of sending the wrong signal.

I return to this point in the conclusion.

${ }^{56}$ In countries where the authorities have manipulated price indices in the past, they may question whether an index specially constructed for use in inflation targeting can be taken at face value. 
In addition, central banks in emerging markets will have an incentive to use transparency to further enhance their credibility. This will tend to push them in the direction of a fullyarticulated inflation-targeting framework rather than the seat-of-the-pants approach preferred by, inter alia, the Federal Reserve. Its hard-won credibility allows the Federal Reserve Board to hint at its inflation forecast rather than announcing it. It allows the Fed to sketch the model used to link its policy instruments to that forecast rather than describing it in any great detail. Most emerging markets do not enjoy this luxury. ${ }^{57}$ To convince investors that they mean what they say, their central banks will have to publish the forecast and the model. Chile, for one, has moved in this direction, while Mexico and Brazil publish an Inflation Report.

Another implication is that effective inflation targeting will require steps to eliminate fiscal dominance as a way of building credibility. In particular, inflation targeting must be supported by the reform and reinforcement of fiscal institutions as a way of delivering better fiscal outcomes. Fiscal-policy making processes and procedures should be centralized to reduce free riding. Vertical fiscal imbalances should be reduced. The budget constraints facing subcentral governments should be hardened. ${ }^{58}$ An example of progress in this direction is Brazil's Fiscal Responsibility Law, which bans the federal government from bailing out debt-ridden states and municipalities and has produced visible improvements in state and municipal fiscal

${ }^{57}$ As Jonas (2000, p.3) writes of the Czech case, "The "just-do-it" approach to monetary policy probably would not be very effective in bringing inflation expectations and actual inflation down. Public announcements by the CNB about its expectations of future inflation would also probably not suffice to anchor inflation expectations and persuade economic agents that monetary policy would be actually conducted with the aim to achieve the announced inflation."

${ }^{58}$ There is evidence that more centralized and hierarchical fiscal policy-making processes lead to better fiscal outcomes and that large vertical imbalances heighten bailout and inflation risk (von Hagen and Eichengreen 1996). 
performance. The federal fiscal authorities, for their part, can invest in the monetary regime so as to intentionally incur costs if it fails, further limiting problems of time inconsistency. Thus, inflation targets in a number of emerging markets are announced not by the central bank but by the government (Chile, Poland) or by the central bank and government jointly (Brazil, Israel) precisely as a way for the government to commit to the fiscal discipline needed to achieve the target.

These implications are evident in the behavior of those emerging markets that have embraced inflation targeting. Such countries have generally moved toward the adoption of a formal framework. Their central banks have been reluctant to miss the inflation target even temporarily, or to slow the pace at which deviations between target inflation and actual inflation are eliminated, for fear of undermining their anti-inflationary credibility. ${ }^{59}$ The credibility problem has tended to dictate that the change in the CPI must be the operational measure of inflation, because it is widely understood and therefore more credible, even when core inflation purged of import-price fluctuations would be more appropriate in principle. ${ }^{60}$

Credibility problems make inflation targeting less attractive. They imply more volatility and less flexible policy implementation. The question is then how quickly credibility can be

${ }^{59}$ While the Czech Republic and South Africa have escape clauses spelling out in advance the circumstances over which targets may be missed and requiring the central bank to indicate the time frame over which it will attempt to return to the target inflation path, in practice neither country has been willing to utilize the provision.

${ }^{60} \mathrm{Chile}$ is thus said to have chosen "a clear and widely understood index like the headline CPI....[in order] to enhance the communicational effectiveness of inflation targeting." Morande (2000), p.161. From this point of view it is no coincidence that emerging market inflation targeters typically target the CPI while industrial-country inflation targeters generally target core inflation (Schoechter, Stone and Zelmer 2000). 
gained, and whether or not inflation targeting can be part of that process.

\section{Conclusion}

Inflation targeting is the increasingly fashionable alternative for countries unable or unwilling to abolish the national currency. ${ }^{61}$ It is seen as providing a coherent alternative to exchange-rate-based monetary policy strategies that are overly restrictive and crisis prone. But is it feasible for emerging markets?

Inflation targeting is difficult in emerging markets for three reasons: they are open, their liabilities are dollarized, and their policy makers lack credibility. Openness exposes their economies to external disturbances. ${ }^{62}$ It makes inflation forecasting more difficult. And it opens additional, exchange-rate related channels linking the central bank's instruments and targets that operate with very different control lags. Because an inflation-targeting central bank will want to respond differently to exchange rate changes depending on their source and persistence, these problems cannot be solved simply by adding the exchange rate to the standard reaction function. None of this is to suggest that inflation targeting is infeasible in open economies, only that it is more complicated to operate.

Liability dollarization introduces more fundamental complications. Financial institutions and their customers will be saddled with currency mismatches, given the difficulty these countries have in borrowing abroad in their own currencies. Under these circumstances, an

\footnotetext{
${ }^{61} \mathrm{Or}$, in the European case, by joining a monetary union in partnership with the issuers of a recognized international currency.

${ }^{62}$ In this respect, it obviously complicates the execution and effects of any monetary policy operating strategy, and not just inflation targeting. I return to this momentarily.
} 
inflation targeting central bank will be reluctant to let the exchange rate move; it will be unable to partake of the greater flexibility ostensibly offered by that regime.

In practice, whether countries with partially dollarized economies reap any advantages from inflation targeting -- whether the framework will provide even limited scope for policy autonomy, and in particular whether it will enable them to allow the exchange rate to fluctuate more freely -- depends on the exact nature, extent, and effects of their liability dollarization. If even a small depreciation of the exchange rate threatens to destabilize balance sheets and output (in other words, if the country immediately enters the zone where depreciation and lower interest rates are recessionary), then the central bank will be unwilling to let the exchange rate to move. In this case, inflation targeting and a hard peg are basically indistinguishable. If the perceived advantage of inflation targeting is that it permits a greater flexibility, then the advantages of inflation targeting are correspondingly less in highly dollarized economies. Inflation targeting has no obvious advantages under these circumstances, while a hard peg has the advantages of simplicity, transparency and credibility.

For countries where the adverse balance sheet effects dominate only when exchange rate movements reach a certain point, conventional inflation targeting will be viable so long as shocks and corresponding exchange rate movements are small, while the desire to intervene and stabilize the exchange rate will dominate when they grow large. The greater exchange rate flexibility promised by inflation targeting will be possible, although the central bank's appetite for indulging in it will have limits.

Such countries will wish to implement inflation targeting in flexibly, by adjusting monetary policy in response to large exchange rate movements, for example, while treating small 
movements with benign neglect. Unfortunately, flexibility can be destabilizing when credibility is lacking. A central bank that temporarily disregards a surge in inflation in order to, say, stabilize the financial system may find its commitment to price stability questioned. Credibility problems will force precisely those emerging markets where a flexible approach to inflation targeting is most valuable to adopt a relatively rigid version. ${ }^{63}$

These observations suggest what countries should find inflation targeting attractive. Inflation targeting will be less attractive the more open the economy, for the reasons detailed several paragraphs back. Note the consonance of this argument with a key implication of theory of optimum currency areas. Inflation targeting will be less attractive the dimmer the prospects of the central bank acquiring policy credibility. Note this time the consonance of this argument with the idea that countries in crisis whose credibility has been shredded should rebuild their reputations by dollarizing. Finally, inflation targeting will be more attractive where liability dollarization is limited and banks and corporations have markets on which to hedge their

${ }^{63}$ Even if they do, questions about the central bank's intentions and independence mean that financial variables and the nonfinancial magnitudes they affect will be more volatile than in a country whose inflation-targeting central bank enjoys greater credibility. Under such circumstances, it is unrealistic to promise that volatility will fall to the levels enjoyed by advanced-industrial economies that target inflation. The same is true, of course, of any other monetary regime so long as the financial system is fragile, the commitment to fiscal discipline is questionable, and the economy is subject to foreign disturbances. A dollarized emerging market subject to these conditions will similarly be more volatile than the typical advanced-industrial country. Some may argue that the very act of dollarizing can solve all problems of financial fragility. Others will suggest that explicit inflation targeting can solve problems of fiscal indiscipline. If either argument is correct, then it creates a strong presumption in favor of one or the other of these regimes. But most readers presumably believe that financial problems have deeper roots than simply the monetary regime, and that fiscal problems are a function of more than just the availability of seignorage revenues. This is just another way of saying that a mere change in monetary regime is unlikely to solve all problems of economic development, miraculously transforming developing countries into G7 nations. 
exposures, so that limited exchange rate fluctuations will not irreparably damage their balance sheets. Note here the consonance of this observation with popular explanations for the success of inflation targeting in Brazil.

On the other hand, emerging markets that are less open, that have well regulated financial institutions and markets on which foreign exposures can be hedged, and whose central banks possess a reasonable degree of policy credibility may prefer inflation targeting. The question is how many emerging markets will soon fall under this heading. 


\section{References}

Aghion, Philippe, Philippe Bachetta and Abijit Banerjee (1999), "Capital Markets and Instability in Open Economies," unpublished manuscript, Study Center Gerzensee.

Armour, Jamie and Agathe Cote (1999-2000), "Feedback Rules for Inflation Control: An Overview of Recent Literature," Bank of Canada Review (Winter), pp.43-54.

Ball, Lawrence (1999), "Policy Rules for Open Economies," in John Taylor (ed.), Monetary Policy Rules, Chicago: University of Chicago Press, pp.127-156.

Ball, Lawrence (2000), "Policy Rules and External Shocks," NBER Working Paper no. 7910 (September).

Bernanke, Ben, Thomas Lubach, Frederic Mishkin and Adam Posen (1999), Inflation Targeting: Lessons from the International Experience, Princeton: Princeton University Press.

Bharucha, Nargis and Christopher Kent (1998), "Inflation Targeting in a Small Open Economy," Discussion Paper no. 98-07, Reserve Bank of Australia (July).

Bogdanski, Joel, Alexandre Tombini and Sergio Werlang (2000), "Implementing Inflation Targeting in Brazil,” Working Paper no. 1, Central Bank of Brazil (July).

Calvo, Guillermo (1986), “Temporary Stabilization: Predetermined Exchange Rates," Journal of Political Economy 94, pp.1319-1329.

Calvo, Guillermo (2000a), “The Case for Hard Pegs," unpublished manuscript, University of Maryland at College Park.

Calvo, Guillermo (2000b), "Capital Markets and the Exchange Rate, with Special Reference to the Dollarization Debate in Latin America," unpublished manuscript, University of Maryland at College Park.

Calvo, Guillermo and Carmen Reinhart (2000), "Fear of Floating," NBER Working Paper no. 7993 (November).

Cepedes, Luis Felipe, Roberto Chang and Andres Velasco (2001), "Dollarization of Liabilities, Net Worth Effects, and Optimal Monetary Policy," unpublished manuscript, NYU, Rutgers and Harvard University.

Christoffersen, Peter and Robert Wescott (1999), “Is Poland Ready for Inflation Targeting?” IMF Working Paper no. 99/41 (March). 
Cooper, Richard (1999), "Exchange Rate Choices," in Jane Sneddon Little and Giovanni Olivei (eds), Rethinking the International Monetary System, Boston: Federal Reserve Bank of Boston, pp.99-123.

De Brouwer, G. and J. O’Regan (1997), "Evaluating Simple Monetary-Policy Rules for Australia," in Philip Lowe (ed.), Monetary Policy and Inflation Targeting, Sydney: Reserve Bank of Australia, pp.244-276.

Devereux, Michael and Philip Lane (2000), "Exchange Rates and Monetary Policy in Emerging Market Economies," unpublished manuscript, University of British Columbia and Hong Kong Monetary Authority.

Eichengreen, Barry (2000), "When to Dollarize," Journal of Money, Credit and Banking (forthcoming).

Eichengreen, Barry, Paul Masson, Miguel Savastano and Sunil Sharma (1999), "Transition Strategies and Nominal Anchors on the Road to Greater Exchange Rate Flexibility," Essays in International Finance no.213, International Finance Section, Department of Economics, Princeton University (April).

Freedman, Charles (1994), "The Use of Indicators and of the Monetary Conditions Index in Canada," in Tomas J.T. Balino and Carlo Cottarelli (eds), Frameworks for Monetary Stability, Washington, D.C.: International Monetary Fund, pp.458-477.

Gomez, Javier (2000), "Inflation Targeting and Openness," unpublished manuscript, Central Bank of Colombia.

Hausmann, Ricardo (1999), "Should There Be 5 Currencies or 105?" Foreign Policy 122, pp.4453.

Hoffmaister, Alexander (1999), "Inflation Targeting in Korea: An Empirical Exploration," IMF Working Paper no. WP/99/7, Washington, D.C.: IMF (January).

Hunt, Ben (1999), “Inter-Forecast Monetary Policy Implementation: Fixed-Instrument versus MCI-Based Strategies," Discussion Paper no. G99/1, Reserve Bank of New Zealand (March).

International Monetary Fund (1999), Hungary: Selected Issues, IMF Staff Country Report no. 99/27, Washington, D.C.: IMF.

J. P. Morgan (2001), "Hungary Joings Inflation Targeting Club 'Implicitly'," Global Data Watch 15 June, pp.11-12.

Jonas, Jiri (2000), "Inflation Targeting in Transition Economies: Some Issues and Experience," 
in Warren Coats (ed.), Inflation Targeting in Transition Ecoomies: The Case of the Czech Republic (forthcoming).

Krugman, Paul (2001), “Crises: The Next Generation,” unpublished manuscript, Princeton University.

Kumhof, Michael (2000), "Inflation Targeting Under Imperfect Credibility,” unpublished manuscript, Department of Economics, Stanford University.

Leiderman, Leo and Gil Bufman (2001), "Surprises on Israel's Road to Exchange Rate Flexibility," Emerging Markets Research, Deutsche Bank, 23 March.

Levin, Andrew, Volker Wieland and John C. Williams (1999), "Robustness of Simple Monetary Policy Rules Under Model Uncertainty,” in John Taylor (ed.), Monetary Policy Rules, Chicago: University of Chicago Press, pp.263-299.

Mahadeva, Lavan and Gabriel Stern, eds. (2000), Monetary Policy Frameworks in a Global Context, London: Routledge.

Masson, Paul (1999), "Monetary and Exchange Rate Policy of Transition Economies of Central and Eastern Europe After the Launch of EMU," Policy Discussion Paper no. PDP/99/5, International Monetary Fund (July).

Masson, Paul, Miguel Savastano and Sunil Sharma (1997), "The Scope for Inflation Targeting in Developing Countries,” IMF Working Paper no. 130 (October).

Mishkin, Frederic (2000a), "Inflation Targeting for Emerging-Market Economies," American Economic Review Papers and Proceedings 90, pp.105-109.

Mishkin, Federic (2000b), "Issues in Inflation Targeting," in Bank of Canada, Price Stability and the Long-Run Target for Monetary Policy, Ottawa: Bank of Canada (forthcoming).

Mishkin, Frederic (2001), "Financial Policies and the Prevention of Financial Crises in Emerging Market Economies,” NBER Working Paper no. 8087 (January).

Mishkin, Frederic and Miguel Savastano (2000), "Monetary Policy Strategies for Latin America,” NBER Working Paper no. 7617 (March).

Morande, Felipe G. (2000), “A Decade of Inflation Targeting in Chile: Main Developments and Lessons," in Charles Joseph and Anton Gunawan (eds), Monetary Policy and Inflation Targeting in Emerging Economies, Jakarta: Bank Indonesia, pp.149-179.

Mundell, Robert (2000), “The International Monetary System in the $21^{\text {st }}$ Century,” Latrobe, 
Penn.: St. Vincent's College.

Rivas, Luis A. (2001), "Underlying Inflation Measures as Short-Run Inflation Targets in Developing Economies: The Case of Nicaragua," unpublished manuscript, Central Bank of Nicaragua.

Ryan, Chris and Christopher Thompson (2000), "Inflation Targeting and Exchange Rate Fluctuations in Australia," Research Discussion Paper 2000-06, Reserve Bank of Australia (September).

Sachs, Jeffrey A. (1980), "Wages, Flexible Exchange Rates, and Macroeconomic Policy," Quarterly Journal of Economics 94, pp.737-747.

Schaechter, Andrea, Mark R. Stone and Mark Zelmer (2000), “Adopting Inflation Targeting: Practical Issues for Emerging Market Countries," Occasional Paper no. 202, Washington, D.C.: IMF.

Svensson, Lars (1996), "Commentary," in Federal Reserve Bank of Kansas City, Achieving Price Stability, Kansas City: Federal Reserve Bank of Kansas City, pp.209-228.

Svensson, Lars (1997), "Inflation Forecast Targeting: Implementing and Monitoring Inflation Targeting," European Economic Review 41, pp.1111-1146.

Svensson, Lars (1999), "Inflation Targeting as a Monetary Policy Rule," Journal of Monetary Economics 43, pp.607-654.

Svensson, Lars (2000), “Open-Economy Inflation Targeting,” Journal of International Economics 50, pp.155-183.

Taylor, John B. (1993), "Discretion Versus Policy Rules in Practice," Carnegie Rochester Conference Series on Public Policy 39, pp.195-214.

Von Hagen, Juergen and Barry Eichengreen (1996), "Fiscal Restraints, Federalism and European Monetary Union: Is the Excessive Deficit Procedure Counterproductive?" American Economic Review Papers and Proceedings 86, pp.134-138.

Williamson, John (2000), "Exchange Rate Regimes for Emerging Markets: Reviving the Intermediate Option," Policy Analyses in International Economics 60, Washington, D.C.: Institute for International Economics. 